\title{
PENGARUH SOCIAL NETWORKING, BIAYA KULIAH DAN PELAYANAN TERHADAP PENGAMBILAN KEPUTUSAN KULIAH DI FAKULTAS EKONOMI DAN BISNIS UNIVERSITAS TJUT NYAK DHIEN MEDAN
}

\author{
Hajatina \\ Akademi Perniagaan dan Perusahaan APIPSU, Diploma III Manajemen \\ Email: Arsyie39@gmail.com
}

\begin{abstract}
The supporting elements that play an active role in all sectors include education. In improving the quality of education, educational institutions must maximize quality learning patterns in the face of developments in science and technology. This study concluded that there was a significant influence both partially and simultaneously between social networking variables (x1) of 0.013 , tuition fees $(\mathrm{x} 2)$ of 0.005 and services $(\mathrm{x} 3)$ of 0.010 on new student admissions at the Faculty of Economics and Business with alpha 0,05\%.
\end{abstract}

Keywords: Social networking, Price, service, college decision making.

\begin{abstract}
Abstrak
Unsur pendukung yang berperan aktif di segala bidang antara lain pendidikan. Dalam meningkatkan mutu pendidikan, lembaga pendidikan harus memaksimalkan sistem pembelajaran yang bermutu dalam menghadapi perkembangan ilmu pengetahuan dan teknologi. Hasil penelitian ini menunjukkan terdapat pengaruh signifikan baik secara parsial maupun secara simultan antara variabel social netwoking (x1) sebesar 0,013 , biaya kuliah (x2) sebesar 0,005 dan pelayanan (x3) sebesar 0,010 terhadap penerimaan mahasiswa baru di Fakultas Ekonomi dan Bisnis dengan alfa $0,05 \%$.
\end{abstract}

Kata Kunci: Social networking, harga, pelayanan, pengambilan keputusan kuliah

1. Pendahuluan

Salah satu aspek pendukung yang menentukan seseorang memutuskan untuk kuliah adalah Social networking. Keadaan ini tidak banyak terlihat diberbagai universitas swasta di Medan khususnya Fakultas Ekonomi dan Bisnis UTND. Banyak cara yang dapat dilaksanakan oleh Fakultas Ekonomi dan Bisnis UTND dalam meningkatkan jumlah mahasiswa antara lain harus selalu kekinian di dalam pemberian informasi, pelayanan maksimal, sehingga mampu mendukung peningkatan jumlah mahasiswa.

Dalam era globalisasi, Pendidikan Tinggi harus mampu meningkatkan kemampuan lulusan dibidang ilmu pengetahuan dan teknologi yang akan menghasilkan lulusan siap pakai, berintelektual tinggi, professional dibidangnya, kreatif, terbuka, berkaraktek, serta memiliki sikap nasionalisme hal ini tertuang dalam Undang-Undang Republik Indonesia Nomor 12 Tahun 2012 tentang 
Perguruan Tinggi. Untuk itu haruslah ada dasar hukum yang kuat. Undang-Undang Nomor 20 Tahun 2003 dapat dijadikan sebagai dasar hukum untuk membangun pendidikan nasional yaitu diterapkannya asas demokrasi, desentralisasi, otonomi, keadilan dan menjunjung tinggi hak asasi manusia.

Menyiapkan pembelajaran perlu disinergikan dengan tuntutan kompetisi sesuai dengan kerangka globalisasi. Human Resources (HR) menjadi aspek terpenting dalam persaingan nanti, untuk itu dalam proses belajar mengajar di tuntut adanya peningkatan usaha dalam memaksimalkan mutu lulusan. Perguruan Tinggi dituntut mampu meningkatkan kualitas lulusannya. Seiiring dengan perkembangan zaman, maka persaingan antar universitas negeri maupun swasta akan semakin ketat. Masing-masing Universitas akan berusaha semaksimal mungkin bersaing untuk meningkatkan promosi dalam hal menarik simpati calon mahasiswa.

Salah satu investasi jangka panjang dalam meningkatkan kemampuan seseorang adalah melanjutkan studi ke tingkat yang lebih tinggi misalnya keperguruan tinggi setelah menamatkan SMA/SMK. Dalam hal itu ada beberapa aspek yang dapat diajadikan pertimbangan sebagai calon mahasiswa untuk menentukan pilihannya memilih perguruan tinggi, diantaranya adalah tujuan dari studi/kuliah tersebut. Dalam pengambilan keputusan tersebut akan dipikirkan hal-hal akan diharapkan dimasa yang akan datang secara rasional dan objektif tentang hal-hal yang akan diraih atau di cita-citakan nantinya.

Untuk menarik minat mahasiswa universitas Tjut Nyak Dhien melakukan kegiatan promosi bukan hanya secara langsung tetapi juga melalui online dengan mengiklankan dibeberapa situs atau laman social media seperti instagram, facebook, WhatsApp, dan media online lainnya. Selain itu pelayanan kepada calon mahasiswa mulai ditingkatkan. Universitas Tjut Nyak Dhien juga menawarkan beberapa kemudahan dalam pembayaran uang kuliah, serta bantuan beasiswa kepada calon mahasiwa yang kurang mampu dan juga berprestasi. Tetapi pada kenyataannya jumlah calon mahasiswa belum terlalu meningkat atau mencapai target yang telah ditentukan, untuk itu penelitian ini dimaksudkan untuk menganalisis pengaruh Social Networking, biaya kuliah, serta pelayanan terhadap keputusan calon mahasiswa mendaftar kuliah di Universitas Tjut Nyak Dhien khususnya Fakultas Ekonomi dan Bisnis. 
Vol. 1 No. 2 Bulan Oktober - Maret 2021

\section{Tinjauan Pustaka}

\subsection{Social Networking}

Jaringan yang menghubungkan antara pemakai komputer yang satu dengan pemakai computer yang lain dan memiliki cakupan luas yaitu ke seluruh penjuru dunia dapat diartikan sebagai Social networking. Sedangkan yang menjadi dasar kata internet terdiri dari dua suku kata yaitu inter dan networking yang artinya adalah suatu standar komunikasi yang digunakan untuk berkomunikasi melalui gabungan jaringan komputer dengan bermacam-macam model. Selanjutnya, internet dapat juga di sebut sebagai jaringan yang dapat di manfaatkan untuk saling berinteraksi serta bertukar informasi melalui beberapa Komputer yang saling berhubungan.

Social networking berdasarkan deskripsi dari Malita (2011) yaitu suatu budaya dari sekumpulan orang yang menggunakan teknologi online sebagai tempat berbagi pemikiran, pandangan, pengalaman, dan pengetahuan yang dapat berbentuk gambar, tulisan, suara, maupun video. Sedangkan defenisi Social networking berdasarkan pendapat Evans (2008) adalah adanya perubahan yang diakibatkan oleh kebebasan informasi dan mengakibatkan aktor pembaca konten menjadi penerbit konten. Keadaan ini diawali dari dialog antara penulis, orangorang dan rekanan yang mengakibatkan peralihan prosedur dari sebuah model ke model lainnya. Agar dapat terhubung secara bersamaan terhadap suatu informasi maka Social networking menggunakan "konsep orang banyak".

Internet, jika dikaji dari sisi ilmu pengetahuan dapat di artikan sebagai perpustakaan yang merupakan sebuah sarana yang efektif dan efisien berisikan segala informasi baik berupa teks, grafik, audio, maupun animasi elektronik dan digunakan sebagai tempat pertukaran informasi jarak jauh.

Sarwono (2008) networking yaitu gabungan dari berbagai jaringan dengan lingkup global, Social networking dapat mengubah jarak yang dahulunya jauh menjadi sangat dekat sehingga hubungan yang diciptakan semakin dekat. Implementasi dari fungsi social networking berfokus pada jaringan yang akan dikembangkan dari satu orang ke orang lainnya, berupa jalinan persahabatan, keluarga, acara atau kegiatan, profesi sampai iklan Boyd dan Ellison, ( 2007).

Suatu jaringan dimana didalamnya terdapat interaksi antara calon mahasiswa dengan calon mahasiswa lainnya dan menciptakan kedekatan diantara mereka 
yang menghasilkan kegiatan pemasaran dapat disebut dengan situs pemasaran. Ada berbagai bentuk promosi daring yang tersedia di dunia maya, dimana masingmasing aplikasi tersebut memiliki keunggulan dan kelemahan, untuk itu harus disesuaikan dengan tujuan pemasangan iklan, tujuan social networking dan harga yang ditawarkan. Melalui social networking, mahasiswa ataupun calon mahasiswa dapat berinteraksi diantara mereka menggunakan media internet, media itu dapat berupa aplikasi laman Facebook, Twitter, WhatsApp, Instagram dan sebagainya. Promosi juga dapat dilakukan dengan memasang iklan di beberapa situs yang terkenal dan paling banyak digunakan oleh masyarakat misalnya Facebook, Twitter, Instagram.

\subsection{Biaya Kuliah}

Suatu usaha yang dilakukan untuk memperoleh barang atau jasa dengan mengeluarkan sejumlah uang disebut biaya Supriyono (2000). Secara etimologis biaya dapat dipahami sebagai pengeluaran, sedangkan dalam ilmu ekonomi biaya adalah sesuatu yang dikeluarkan berupa uang atau sejenisnya. Secara khusus biaya kuliah/pendidikan dapat didefenisikan menjadi salah satu komponen masukan instrumental (instrumental input) yang sangat penting dalam penyelenggaraan pendidikan Supriadi (2010:3). Lebih jelasnya biaya merupakan seluruh jenis pengeluaran yang bersinggungan dengan penyelenggaraan pendidikan baik berupa uang maupun setaranya.

Menurut Kotler dan Keller (2009), Salah satu inti dari marketing Mix yang menghasilkan pendapatan, dan disisi lain menghasilkan biaya disebut dengan harga. Suatu elemen yang termudah untuk disesuaikan dalam program pemasaran adalah harga dimana dapat disesuaikan dengan fungsi produk, media, bahkan komunikasi.

Sesuai dengan konsep "pertukaran (exchange) dalam pemasaran" maka harga dapat didefenisikan sebagai sesuatu yang dapat di ukur dengan nilai uang atau lainnya (barang atau jasa) jika ditukarkan akan memperoleh hak kepemilikan atau hak guna Tjiptono (2012). Harga sangat berpengaruh kepada pendapatan, karena pendapatan akan mempengaruhi permintaan, tetapi keputusan dalam penetapan harga wajib selaras dengan strategi pemasaran secara utuh.

\subsection{Pelayanan}

Menurut pendapat Kasmir (2017:47) pelayanan merupakan kepuasan yang 
diberikan oleh seseorang atau organisasi kepada customernya maupun sesama pegawai. Sejalan dengan defenisi dia tas maka menurut Sugiarto (2002:216) pelayanan adalah usaha yang diberikan oleh pemberi pelayanan secara maksimal kepada perusahaan industri dengan harapan bahwa kebutuhan dan kepuasan pelangga dapat terpenuhi.

\subsection{Pengambilan keputusan}

Pengambilan keputusan adalah suatu pilihan yang didasarkan atas kriteria tertentu, biasanya dalam pengambilan keputusan terdapat dua atau lebih alternative. Dalam pengambilan keputusan untuk kuliah biasanya calon mahasiswa sudah mempertimbangkan alternativealternatif yang akan diambilnya.

\section{Metode Penelitian}

Penelitian ini dilakukan melalui pengumpulan data dan analisis kuantitatif (kuesioner) yang memiliki tujuan untuk mengetahui pengaruh social networking, biaya kuliah, pelayanan terhadap keputusan kuliah di Fakultas Ekonomi dan Bisnis UTND.

Populasi penelitian ini adalah seluruh Mahasiswa Fakultas Fakultas Ekonomi dan Bisnis angkatan 2019 yang berjumlah 120 orang. Dan yang menjadi sampel pada penelitian ini adalah seluruh mahasiswa Fakultas Ekonomi dan Bisnis angkatan tahun 2019.

Teknik pengumpulan data pada penelitian diperlukan untuk mengetahui kebenaran data dan informasi yang. Oleh sebab itu teknik pengumpulan data yang digunakan adalah:

1. Studi kepustakaan yaitu data diperoleh melalui berbagai daftar bacaan yang berhubungan dengan penelitian ini

2. Studi lapangan yaitu data diperoleh melalui hubungan langsung dengan objek penelitian untuk mengetahui inti permasalahan yang biasa dikenal dengan data primer biasanya menggunakan:

a. Kuesioner, merupakan suatu alat untuk memperoleh data dari sampel penelitian yang telah ditentukan.

b. Dokumentasi, merupakan cara untuk mengumpulkan data serta mengolahnya melalui informasi yang diperoleh yang berhubungan dengan masalah yang diteliti.

c. Wawancara, merupakan bentuk memperoleh data dengan tanya jawab.

Yang menjadi variabel bebas dalam tulisan ini adalah social Networking, biaya kuliah, dan pelayanan, Sedangkan variabel 
Vol. 1 No. 2 Bulan Oktober - Maret 2021

terikatnya adalah keputusan mahasiswa untuk kuliah di Universitas Tjut Nyak Dhien Fakultas Ekonomi dan Bisnis.

Penelitian ini menggunakan metode deskriptif kuantitatif dengan model analisis Regresi Linier Berganda. Adapun Defenisi operasional dan indikator dari penelitian ini adalah:

1. Social Networking (x1) merupakan media berbasis internet yang memungkinkan adanya pertukaran komunikasi dan informasi antara fakultas dan mahasiswa. Dengan indicator peneltian (a). Media social memberikan informasi yang jelas mengenai program studi; (b). Media social membantu berkomunikasi dengan fakultas untuk informasi yang lebih lengkap; (c). mendapatkan testimon dari anggota lain; (d). dapat melakukan complain melaui media social jika ada kendala

2. Biaya kuliah (X2) merupakan seluruh biaya operasional dihitung per mahasiswa untuk setiap semesternya pada setiap program studi. Indicator penelitiannya adalah: (a). Biaya/harga uang kuliah terjangkau oleh seluruh mahasiswa; (b). harga yang ditawarkan sesuai dengan mutu yang diharapkan oleh mahasiswa; (c). harga yang ditawarkan sebanding dengan manfaat yang diterima; (d). uang kuliah ditawarkan dapat bersaing dengan perguruan tinggi yang sejenis

3. Pelayanan (x3) merupakan usaha yang diberikan oleh pemberi pelayanan secara maksimal kepada calon mahsiswa dengan harapan bahwa kebutuhan calon mahasiswa dapat terpenuhi sepenuhnya. Dengan indicator penelitian (a). disiplin, sopan dan ramah; (b). kenyamanan; (c). kemudahan akses; dan (d). kepastian waktu.

4. Keputusan kuliah (Y) merupakan usaha yang dilakukan oleh calon mahasiswa secara langsung dalam usahanya untuk kuliah pada Fakultas Ekonomi dan Bisnis sebagai tempat kuliah. Dengan indikator penelitian (a). Pencarian informasi; (b). Mengevaluasi penawaran (c). analisis alternative; dan (d). melaksanakan keputusan

Penelitian ini menggunakan teknik skala Likert. Skala Likert bertujuan untuk mengukur fenomena sosial, sikap, pendapat dan pandangan seseorang maupun kelompok. 


\section{Hasil Penelitian dan Pembahasan}

\subsection{Hasil Penelitian}

4.1.1. Uji validitas dan reabilitas

Tabel 1. Uji validitas social networking (x1)

\begin{tabular}{|l|r|r|r|r|}
\multicolumn{7}{|c|}{ Item-Total Statistics } \\
\hline & $\begin{array}{c}\text { Scale Mean if } \\
\text { Item Deleted }\end{array}$ & $\begin{array}{c}\text { Scale } \\
\text { Variance if } \\
\text { Item Deleted }\end{array}$ & $\begin{array}{c}\text { Corrected } \\
\text { Item-Total } \\
\text { Correlation }\end{array}$ & $\begin{array}{c}\text { Cronbach's } \\
\text { Alpha if Item } \\
\text { Deleted }\end{array}$ \\
\hline x1.1 & 13,9917 & 1,655 &, 525 &, 695 \\
x.1.2 & 14,0667 & 1,441 &, 645 &, 617 \\
x.1.3 & 13,8667 & 1,965 &, 504 &, 704 \\
x.1.4 & 13,8000 & 2,027 &, 511 &, 704 \\
\hline
\end{tabular}

Tabel 2. Uji validitas biaya kuliah (x2)

\begin{tabular}{|c|r|r|r|r|}
\hline & $\begin{array}{c}\text { Item-Total Statistics } \\
\text { Scale Mean if }\end{array}$ & $\begin{array}{c}\text { Scale } \\
\text { Variance if } \\
\text { Item Deleted }\end{array}$ & $\begin{array}{c}\text { Corrected } \\
\text { Item-Total } \\
\text { Correlation }\end{array}$ & $\begin{array}{c}\text { Cronbach's } \\
\text { Alpha if Item } \\
\text { Deleted }\end{array}$ \\
\hline x.2.1 & 13,7333 & 1,794 &, 508 &, 674 \\
x.2.2 & 13,8250 & 1,675 &, 593 &, 619 \\
x.2.3 & 13,7083 & 1,923 &, 529 &, 660 \\
x.2.4 & 13,6333 & 2,100 &, 446 &, 705 \\
\hline
\end{tabular}

Tabel 3. Uji validitas pelayanan (x3)

\begin{tabular}{|c|c|r|r|r|}
\hline \multicolumn{5}{|c|}{ Item-Total Statistics } \\
\hline & $\begin{array}{c}\text { Scale Mean if } \\
\text { Item Deleted }\end{array}$ & $\begin{array}{c}\text { Scale } \\
\text { Variance if } \\
\text { Item Deleted }\end{array}$ & $\begin{array}{c}\text { Corrected } \\
\text { Item-Total } \\
\text { Correlation }\end{array}$ & $\begin{array}{c}\text { Cronbach's } \\
\text { Apha if Item } \\
\text { Deleted }\end{array}$ \\
\hline x.3.1 & 12,5083 & 3,059 &, 626 &, 684 \\
x.3.2 & 12,5333 & 3,259 &, 576 &, 711 \\
x.3.3 & 12,6917 & 2,887 &, 511 &, 745 \\
x.3.4 & 12,4167 & 2,665 &, 587 &, 702 \\
\hline
\end{tabular}

Tabel 4. Uji validitas keputusan kuliah (Y)

\begin{tabular}{|l|r|r|r|r|}
\hline & $\begin{array}{c}\text { Item-Total Statistics } \\
\text { Item Deleted }\end{array}$ & $\begin{array}{c}\text { Scale } \\
\text { Variance if } \\
\text { Item Deleted }\end{array}$ & $\begin{array}{c}\text { Corrected } \\
\text { Item-Total } \\
\text { Correlation }\end{array}$ & $\begin{array}{c}\text { Cronbach's } \\
\text { Alpha if Item } \\
\text { Deleted }\end{array}$ \\
\hline y1 & 13,4083 & 2,076 &, 583 &, 762 \\
y2 & 13,4417 & 2,198 &, 571 &, 767 \\
y3 & 13,4000 & 1,956 &, 724 &, 691 \\
y4 & 13,4000 & 2,091 &, 572 &, 768 \\
\hline
\end{tabular}

Berdasarkan hasil uji validitas social networking (x1), biaya kuliah (x2), pelayanan (x3) dan keputusan kuliah (y) dengan 120 orang responden dinyatakan seluruh butir adalah valid, Nilai corrected item - total correlation $(0.1793)>\mathrm{r}$ tabel.
Tabel. 5 Uji reliabilitas social networking (x1)

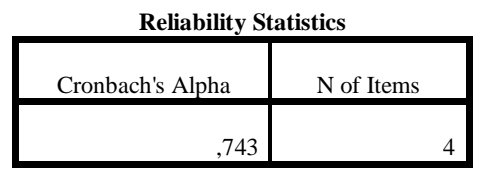

Tabel 6. Uji Reliabilitas biaya kuliah (x2)

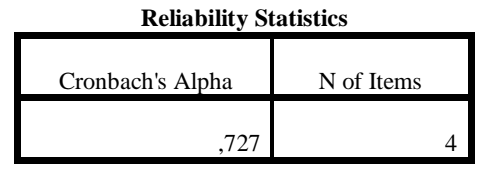

Tabel 7. Uji reliabilitas pelayanan (x3)

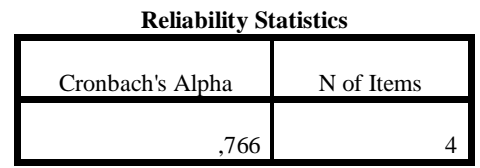

Tabel 8. Uji Reabilitas keputusan kuliah (Y)

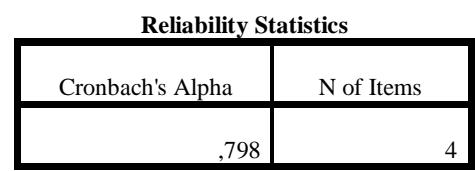

Berdasarkan seluruh hasil uji realibilitas yang terdiri dari social networking (x1), biaya kuliah (x2), pelayanan (x3) dan keputusan kuliah Y dinyatakan seluruh butir adalah reliabel dengan nilai cronbach's Alpha $>0.60$.

\subsubsection{Uji asumsi klasik}

\section{Tabel 9. Uji Normalitas}

One-Sample Kolmogorov-Smirnov Test

\begin{tabular}{|ll|r|}
\hline & & $\begin{array}{r}\text { Unstandardiz } \\
\text { ed Residual }\end{array}$ \\
\hline Normal Parameters ${ }^{\mathrm{a}, \mathrm{b}}$ & Mean & 120 \\
& Std. Deviation &, 0000000 \\
Most Extreme Differences & Absolute & 1,65180523 \\
& Positive &, 083 \\
& Negative &, 057 \\
Kolmogorov-Smirnov $Z$ & &,- 083 \\
Asymp. Sig. (2-tailed) & &, 905 \\
\hline
\end{tabular}

a. Test distribution is Normal.

b. Calculated from data. 
Berdasarkan hasil uji normalitas diatas nilai Asymp. Sig. (2-tailed) sebesar 0.386> 0.05 maka dinyatakan seluruh data berdistribusi normal.

Tabel 10. Uji multikolinearitas

Coefficients $^{\mathrm{a}}$

\begin{tabular}{|rr|r|r|}
\hline \multicolumn{2}{|l|}{ Model } & \multicolumn{2}{|c|}{ Collinearity Statistics } \\
\cline { 3 - 4 } & & Tolerance & \multicolumn{1}{c|}{ VIF } \\
\hline 1 & x1 &, 731 & 1,368 \\
& X2 &, 733 & 1,364 \\
& x3 &, 995 & 1,005 \\
\hline
\end{tabular}

a. Dependent Variable: $Y$

Berdasarkan hasil uji multikolinearitas diketahui nilai tolerance untuk social networking (x1), biaya kuliah (x2) dan pelayanan (3) yaitu 0,731 ; 0,733 ; dan 0,995 $>0,10$ sementara nilai VIF untuk variabel social networking (x1), biaya kuliah (x2) dan pelayanan (x3) yaitu 1.368;1,364; dan 1,005 <10 maka dapat disimpulkan bahwa tidak terjadi gejala multikolinearitas pada model regresi ini.

\section{Tabel 11. Uji heteroskedastisitas}

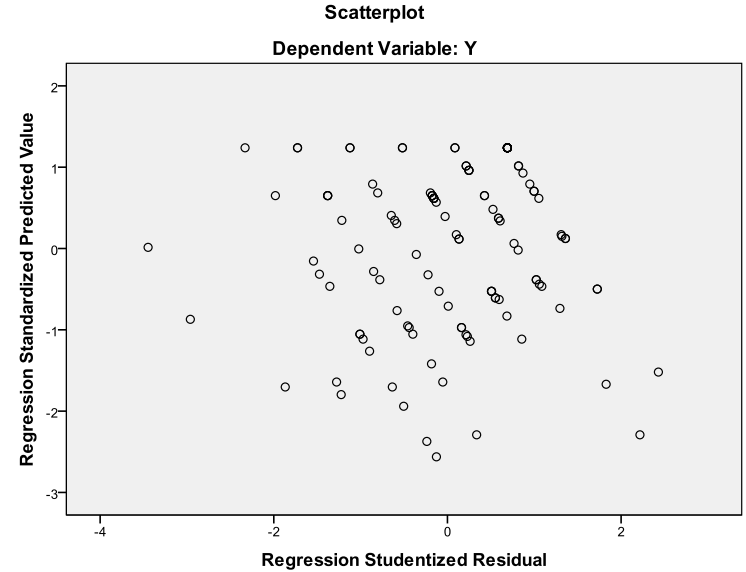

Berdasarkan scatterplot diatas dapat disimpulkan bahwa titik titik menyebar tidak membentuk pola tertentu dan menyebar baik di atas angka nol maupun dibawah angka nol artinya, model regresi ini bebas dari masalah heteroskedastisitas sehingga model regresi ini layak digunakan.

\subsubsection{Uji regresi}

\section{Tabel 12. Uji t (parsial)}

\begin{tabular}{|c|c|c|c|c|c|c|}
\hline \multicolumn{7}{|c|}{ Coefficients $^{\mathrm{a}}$} \\
\hline \multirow{2}{*}{\multicolumn{2}{|c|}{ Model }} & \multicolumn{2}{|c|}{ Unstandardized Coefficients } & \multirow{2}{*}{$\begin{array}{c}\text { Standardized } \\
\text { Coefficients }\end{array}$} & \multirow[b]{2}{*}{$t$} & \multirow[b]{2}{*}{ Sig. } \\
\hline & & B & Std. Error & & & \\
\hline \multirow[t]{4}{*}{1} & (Constant) & 3,256 & 2,354 & & 1,383 & 169 \\
\hline & $\mathrm{x} 1$ & ,267 & ,105 & 238 & 2,532 & ,013 \\
\hline & $\times 2$ & ,299 & 104 & 270 & 2,886 &, 005 \\
\hline & $x_{3}$ & 214 &, 082 & ,211 & 2,619 &, 010 \\
\hline
\end{tabular}

Nilai sig. untuk variabel social networking (x1) yaitu 0,013, biaya kuliah (x2) yaitu 0.005 dan pelayanan (x3) yaitu 0,010 seluruh variabel dinyatakan berpengaruh terhadap keputusan kuliah karena nilai sig. $<0,05$.

Tabel 13. Uji F (simultan)

\begin{tabular}{|c|c|c|c|c|c|c|}
\hline \multicolumn{7}{|c|}{ ANOVA $^{\text {b }}$} \\
\hline Mod & & $\begin{array}{l}\text { Sum of } \\
\text { Squares }\end{array}$ & df & Mean Square & $\mathrm{F}$ & Sig. \\
\hline \multirow[t]{3}{*}{1} & Regression & 109,980 & 3 & 36,660 & 13,097 &, $000^{\mathrm{a}}$ \\
\hline & Residual & 324,687 & 116 & 2,799 & & \\
\hline & Total & 434,667 & 119 & & & \\
\hline
\end{tabular}

Berdasarkan hasil dari uji $\mathrm{F}$ yaitu nilai sig. $0.000<0,05$ maka variabel social networking (x1), biaya kuliah (x2) dan pelayanan (x3) berpengaruh secara simultan terhadap keputusan kuliah (y). 


\subsubsection{Uji koefisien determinasi}

Tabel 14. Uji determinasi

Model Summary

\begin{tabular}{|l|l|r|r|r|}
\hline Model & $\mathrm{R}$ & R Square & \multicolumn{1}{c|}{$\begin{array}{c}\text { Adjusted } \mathrm{R} \\
\text { Square }\end{array}$} & $\begin{array}{c}\text { Std. Error of } \\
\text { the Estimate }\end{array}$ \\
\hline 1 &, $503^{\mathrm{a}}$ &, 253 &, 234 & 1,67303 \\
\hline
\end{tabular}

a. Predictors: (Constant), x3, X2, x1

b. Dependent Variable: $Y$

Berdasarkan hasil perhitungan uji determinasi di atas diketahui nilai $\mathrm{R}$ square yaitu 0,253 artinya variabel bebas social networking (x1), biaya kuliah (x2) dan pelayanan (x3) mempengaruhi keputusan kuliah hanya sebesar $25,3 \%$ dan sisanya dipengaruhi oleh faktor lain yang tidak dijelaskan di dalam penelitian ini seperti tingkat akreditasi, mutu, kualitas tenaga pengajar dan lain sebagainya.

\subsection{Pembahasan}

social networking

mempengaruhi keputusan kuliah sebesar sig. $0.013<0.05$ hal ini disebabkan kemajuan tekhnologi dan ilmu pengetahuan semakin maju berkembang oleh karena itu perguruan tinggi swasta dalam menarik mahasiswa baru mengurangi bentuk promosi secara manual, tetapi lebih menekankan secara daring melalui social media seperti face book, whatsup, instagram, website dana lin sebagainya. Mayoritas calon mahasiwa baru lebih sering searching di dunia maya oleh sebab itu bentuk-bentuk promosi dalam bentuk daring lebih ditingkatkan lagi.
Hasil penelitian ini sesuai dengan penelitian yang dilakukan oleh Rahayu dan Hasanah (2020) yaitu 87,7\% keputusan mahasiswa memilih STMIK royal dipengaruhi promosi melalui social media.

Hasil penelitian secara parsial biaya kuliah (x2) berpengaruh terhadap keputusan kuliah memberikan bukti berdasarkan pengamatan bahwa harga memiliki pengaruh yang paling dominan dalam membentuk keputusan kuliah. Hal ini ditunjukkan melalui nilai sig pada uji parsial (uji t) untuk biaya kuliah $(0,005)$ lebih kecil dari $\alpha$ $=0,05$. Pada dasarnya jika harga (biaya kuliah) semakin tinggi maka akan diikuti dengan sedikitnya peminat yang akan mengambil keputusan kuliah di universitas tersebut. Jika harga uang kuliah terjangkau oleh seluruh mahasiswa maka keputusan kuliah pun akan semakin meningkat.

Hal ini membuktikkan bahwa mayoritas mahasiswa mempersoalkan harga dalam mengambil keputusan kuliah. Kecenderungan tersebut bisa saja disebabkan oleh faktor ekonomi yang tidak dapat dipastikan. Berdasarkan pendapat Kotler dan keller (2012) di dalam bauran pemasaran terdapat suatu unsur yang mampu membangun cara pandang pelanggan atas produk (barang atau jasa) 
yaitu unsur harga. Unsur ini membangun persepsi pelanggan yaitu semakin tinggi harga suatu produk/jasa maka semakin tinggi pula harapan terhadap produk/jasa tersebut. Timbullah harapan bahwa dengan harga yang tinggi maka yang diperoleh produk/jasa lebih baik dari harga yang lebih rendah.

Sejalan dengan Hasil penelitian sebelumnya yang menunjukkan bahwa harga berpengaruh signifikan terhadap keputusan pembelian. Artika, (2016). Hal ini tidak sejalan dengan penelitian yang dilakukan oleh hajatina (2018) yang menyatakan bahwa variabel harga memiliki pengaruh negatif dalam membentuk keputusan kuliah. Dengan demikian dapat disimpulkan bahwa harga belum cukup kuat untuk menciptakan keputusan kuliah.

Pelayan (x3) berpengaruh terhadap keputusan kuliah sebesar 0,010 hal ini sejalan dengan penelitian Syafitri (2017) yang menyatakan bahwa kualitas pelayanan berpengaruh secara parsial terhadap keputusan mahasiswa memilih Fakultas ekonomi universitas musi lawas. Hal ini juga sejalan dengan teori yang dikemukakan oleh kotler (2008) kualitas jasa harus dimulai dari kebutuhan pelanggan dan berakhir dengan kepuasan pelanggan serta persepsi positif terhadap kualitas jasa.

Variabel social networking (x1), biaya kuliah (x2) dan pelayanan (x3) berpengaruh secara simultan terhadap keputusan kuliah (y) hal ini dapat dilihat melalui nilai sig. sebesar $0.000<0.05$. nilai $\mathrm{R}$ square sebesar $0,253 \quad(25,3 \%)$ yang memiliki arti bahwa variabel social networking (x1), biaya kuliah (x2) dan pelayanan (x3) mempengaruhi keputusan calon mahasiswa memilih Fakultas Ekonomi dan Bisnis universitas Tjut Nyak Dhien hanya sebesar 25,3\%. Kemudian sisanya sebesar $74,7 \%$ dipengaruhi oleh faktor lain diluar ketiga variabel diatas (social networking (x1), biaya kuliah (x2) dan pelayanan (x3)) seperti tingkat akreditasi kampus, lulusan tenaga pengajar dan lain sebagainya.

\section{Kesimpulan dan Saran}

\subsection{Kesimpulan:}

a. Secara parsial, berdasarkan nilai sig. social networking (x1) yaitu 0,013 , biaya kuliah (x2) yaitu 0.005 dan pelayanan (x3) yaitu 0,010 masingmasing variabel $>0,05$ artinya masing-masing variabel tersebut berpengaruh terhadap keputusan kuliah. 
b. Secara simultan social networking (x1), biaya kuliah (x2) dan pelayanan (x3) berpengaruh terhadap keputusan kuliah dengan nilai sig. sebesar $0.000<0.05$

\subsection{Saran}

a. Variabel pada penelitian ini tidak mengikut sertakan mutu atau kualitas universitas, diharapkan kedepannya untuk peneliti selanjutnya dapat memperdalam kajian dengan menambahkan unsur mutu dari universitas.

b. Harga merupakan variabel yang paling dominan pada penelitian ini sehingga variabel ini harus dipertahankan serta diiringi juga dengan peningkatan kualitas, semakin baik kualitas dan harga yang ditawarkan juga terjangkau maka akan semakin banyak peminat yang akan kuliah di Fakultas Ekonomi Universitas Tjut Nyak Dhien Medan.

\section{DAFTAR PUSTAKA}

Boyd, Danah M., Ellison, Nicole B., 2007Social Network Sites: Definition, History, and Scholarship, Journal of Computer-Mediated Communication, Vol 13 No 1.

Hajatina. 2018. Pengaruh Social Networking dan harga terhadap keputusan kuliah pada fakultas farmasi swasta dikota medan.Tesis. universitas Sumatera Utara: Medan

Kasmir. (2017). Customer Services Excellent :Teori dan Praktik, Cetakan Ke-1 . Jakarta: Kharisma Putra Utama Offset.

Kotler, Philip dan Keller. 2009. Manajemen Pemasaran. Edisi Ketiga Belas, Jilid 2, Jakarta: Erlangga.

Malita, L., 2011, Social Media Time Management Tolls dan Tips, Procedia Computer Science 3, 747753

Rahayu,Elly dan Hasanah, Uswatun.2020. Sosial media dan pengaruhnya terhadap keputusan mahasiswa memilih STMIK Royal. Journal of science and social research. Volume III no. 1 hal: 33-40.

Sarwono, Jonathan. 2008. Teori ECommerce. Bandung: Gava Media.

Supriadi, Dedi, 2010, Satuan Biaya Pendidikan Dasar dan Menengah, Bandung : PT Remaja Rosdakarya

Supriyono, R.A. 2000. Akuntansi Biaya : Perencanaan dan Pengendalian Biaya serta Pembuatan Keputusan. Edisi Kedua. Buku Kedua. BPFE: Yogyakarta.

Syafitri, Anggia. 2017. Pengaruh kualitas pelayanan, biaya, lokasi dan promosi terhadap keputusan mahasiswa dalam memilih fakultas ekonomi universitas musi rawas. Diakses tanggal 29 agustus 2020 pukul 22:49 WIB. 
Volua Jurnal Ilmiah Akuntansi Keuangan dan Bisnis

Vol. 1 No. 2 Bulan Oktober - Maret 2021

Tjiptono, F. 2012. Strategi Pemasaran.

Edisi Kedua. Yogyakarta: Andi.

Undang-Undang Republik Indonesia Nomor

12 Tahun 2012 tentang Perguruan

Tinggi 